\title{
Letter to editor: careful literature search and exact data extraction are milestones of a meta-analysis: the case of dairy consumption and hip fracture
}

\author{
Hanieh Malmir ${ }^{1,3}$ (1) and Ahmad Esmaillzadeh ${ }^{2,3,4^{*}}$
}

\begin{abstract}
In a recent issue of the BMC Public Health journal, Bian et al. described the results of an interesting meta-analysis on the association between dairy products consumption and risk of hip fracture. Although the results are important and valuable, some critical points should be noticed in the explanation of these findings. We prepared these critical points in a letter to the editor and hope to be an interest of you.
\end{abstract}

Keywords: Milk, Dairy, Hip fracture, Meta-analysis, Letter

\section{Main text}

In a recent issue of the journal, Bian et al. described the results of an interesting meta-analysis on the association between dairy products consumption and risk of hip fracture based on 18 observational studies [1]. They found that consumption of yogurt and cheese was associated with a lower risk of hip fracture. However, they failed to find any significant association between consumption of milk, cream and total dairy consumption and risk of hip fracture. Although, the results are important and valuable, some critical points should be noticed in the explanation of these findings.

First, as we all know, literature search is the most important step in any meta-analysis. Lack of inclusion of relevant studies might influence the whole findings of the meta-analysis. In the study of Bian et al., several publications have been missed and were not included [2-7]. For instance they did not include the study of Sahni et al., which assessed the relation between consumption of dairy and hip fracture in 3224 American adults (2). This is also the case for other studies. Second, although individual

\footnotetext{
* Correspondence: a-esmaillzadeh@tums.ac.ir

2Obesity and Eating Habits Research Center, Endocrinology and Metabolism Molecular Cellular Sciences Institute, Tehran University of Medical Sciences, Tehran, Iran

${ }^{3}$ Department of Community Nutrition, School of Nutritional Sciences and Dietetics, Tehran University of Medical Sciences, P.O. Box 14155-6117, Tehran, Iran

Full list of author information is available at the end of the article
}

publications have reported covariate-adjusted RRs or ORs, the authors did not use these adjusted values and rather they applied crude RRs or ORs [8,9]. Considering the contribution of other variables to hip fracture, it is very important to consider the independent association of dairy intake and risk of hip fracture. The third point is that most studies have reported RRs and ORs for hip fracture in the highest intake of dairy products versus the lowest intake. However, in three publications [10-12] Bian et al. included in the meta-analysis, the risk was reported per 1-cup or per a given grams of dairy consumption per day [10-12]. Bian et al. have combined these effect sizes, while we all know that combination of effect sizes, from studies that considered the exposure as categorical and continuous variables, can distort the overall findings. Finally, in two individual publications $[11,13]$, consumption of dairy products in childhood and adolescence period were linked with risk of hip fracture in adulthood [11, 13], while other included studies have examined dairy consumption in adulthood. Given the difference in dairy consumption between adolescence and adulthood, pooling the findings of these studies might influence the overall findings.

In conclusion, there is a great value in summarizing the relation between consumption of dairy products and risk of hip fracture in a meta-analysis; however, in order to avoid any incorrect conclusions, careful search of literature and data extraction must be done. 


\section{Abbreviations}

OR: Odds ratio; RR: Relative risk

\section{Acknowledgements}

Not applicable

\section{Funding}

This study was financially supported by a joint collaboration of Endocrinology and Metabolism Molecular-Cellular Sciences Institute, Tehran University of Medical Sciences, and School of Nutritional Sciences and Dietetics, Tehran University of Medical Sciences, Tehran, Iran. Dr. Ahmad Esmaillzadeh was supported by a grant from Iran National Science Foundation (INSF).

\section{Availability of data and materials}

The dataset used and analyzed during the current study are available from the corresponding author on reasonable request.

\section{Authors' contributions}

All authors conceived the idea, contributed to the search strategy employed. $\mathrm{HM}$ and $\mathrm{AE}$ conducted the literature search, quality assessment, data extraction and analysis, and wrote the draft manuscript. All authors contributed to the interpretation of the results and critically reviewed the manuscript. All authors read and approved the final manuscript.

\section{Ethics approval and consent to participate}

Not applicable.

\section{Consent for publication}

Not applicable.

\section{Competing interests}

The authors declare they have no competing interests.

\section{Publisher's note}

Springer Nature remains neutral with regard to jurisdictional claims in published maps and institutional affiliations.

\section{Author details}

'Students' Scientific Research Center, Tehran University of Medical Sciences, Tehran, Iran. ${ }^{2}$ Obesity and Eating Habits Research Center, Endocrinology and Metabolism Molecular Cellular Sciences Institute, Tehran University of Medical Sciences, Tehran, Iran. ${ }^{3}$ Department of Community Nutrition, School of Nutritional Sciences and Dietetics, Tehran University of Medical Sciences, P.O. Box 14155-6117, Tehran, Iran. ${ }^{4}$ Food Security Research Center, Department of Community Nutrition, Isfahan University of Medical Sciences, Isfahan, Iran.

Received: 26 August 2018 Accepted: 1 November 2018

\section{Published online: 13 November 2018}

\section{References}

1. Bian S, Hu J, Zhang K, Wang Y, Yu M, Ma J. Dairy product consumption and risk of hip fracture: a systematic review and meta-analysis. BMC Public Health. 2018;18(1):165.

2. Sahni S, Tucker KL, Kiel DP, Quach L, Casey VA, Hannan MT. Milk and yogurt consumption are linked with higher bone mineral density but not with hip fracture: the Framingham offspring study. Arch Osteoporos. 2013;8:119.

3. Slavens MJ, Munger R, Wengreen H, Cutler R, Corcoran C. Milk intake in early and late adulthood and risk of osteoporotic hip fractures in Utah. Osteoporos Int. 2006;17:S155-S.

4. Feskanich D, Willett WC, Colditz GA. Calcium, vitamin D, milk consumption, and hip fractures: a prospective study among postmenopausal women. Am J Clin Nutr. 2003;77(2):504-11.

5. Turner LW, Hunt S, Kendrick O, Eddy J. Dairy product intake and hip fracture among older women: health behavior implications. Res Q Exerc Sport. 1999; 70(1):A47-A

6. Suzuki T, Yoshida H, Hashimoto T, Yoshimura N, Fujiwara S, Fukunaga M, et al. Case-control study of risk factors for hip fractures in the Japanese elderly by a Mediterranean osteoporosis study (MEDOS) questionnaire. Bone. 1997;21(5):461-7.
7. Owusu W, Willett WC, Feskanich D, Ascherio A, Spiegelman D, Colditz GA. Calcium intake and the incidence of forearm and hip fractures among men. J Nutr. 1997;127(9):1782-7.

8. Lan TY, Hou SM, Chen CY, Chang WC, Lin J, Lin CC, et al. Risk factors for hip fracture in older adults: a case-control study in Taiwan. Osteoporos Int. 2010;21(5):773-84.

9. Johnell O, Gullberg B, Kanis JA, Allander E, Elffors L, Dequeker J, et al. Risk factors for hip fracture in european women: the MEDOS study. J Bone Miner Res. 1995;10(11):1802-15.

10. Benetou V, Orfanos P, Zylis D, Sieri S, Contiero P, Tumino R, et al. Diet and hip fractures among elderly Europeans in the EPIC cohort. Eur J Clin Nutr. 2011;65(1):132-9.

11. Nieves JW, Grisso JA, Kelsey JL. A case-control study of hip fracture: evaluation of selected dietary variables and teenage physical activity. Osteoporos Int. 1992;2(3):122-7.

12. Kanis J, Johnell O, Gullberg B, Allander E, Elffors L, Ranstam J, et al. Risk factors for hip fracture in men from southern Europe: the MEDOS study. Mediterranean Osteoporosis Study. Osteoporos Int. 1999;9(1):45-54

13. Feskanich D, Bischoff-Ferrari HA, Frazier AL, Willett WC. Milk consumption during teenage years and risk of hip fractures in older adults. JAMA Pediatr. 2014 Jan;168(1):54-60.

\section{Ready to submit your research? Choose BMC and benefit from:}

- fast, convenient online submission

- thorough peer review by experienced researchers in your field

- rapid publication on acceptance

- support for research data, including large and complex data types

- gold Open Access which fosters wider collaboration and increased citations

- maximum visibility for your research: over $100 \mathrm{M}$ website views per year

At BMC, research is always in progress.

Learn more biomedcentral.com/submission 